\title{
Nematicidal properties of crude extracts obtained from medicinal plants against root- lesion nematode Pratylenchus coffeae
}

\author{
Đặc tính kháng tuyến trùng của các hợp chất chiết xuất tù̀ cây thuốc phòng trì \\ Pratylenchus coffeae gây hại rễ cà phê \\ Research article
}

Nguyen, Dang Minh Chanh*1; Jung, Woo Jin ${ }^{2}$

${ }^{I}$ Center for Agrarian Systems Research and Development (CASRAD), An Khanh, Hoai Duc, Hanoi, Vietnam; ${ }^{2}$ Division of Applied Bioscience and Biotechnology, Institute of Environmentally-Friendly Agriculture (IEFA), Chonnam National University, Gwangju 500-757, South Korea

\begin{abstract}
To investigate nematicidal activity against the root-lesion nematode, Pratylenchus coffeae, the methanolic extracts were obtained from 5 medicinal plants in Vietnam. Methanol extracts of the 5 samples were screened for nematicidal activity against Pratylenchus coffeae in vitro. Of the plant extracts tested, a $5 \mathrm{mg} / \mathrm{ml}$ concentration of Terminalia nigrovenulosa extract showed the highest level $(95.0 \%)$ of nematicidal activity against Pratylenchus coffeae at $9 \mathrm{~h}$ after treatment. The remainder of the plant extracts was followed by Cinnamomum camphora (66.7\%), Jasminum suptriplinerve (30.8\%), Premna integrifolia (6.7\%), and Treptocaulon juventas (5.8\%). A $2.0 \mathrm{mg} / \mathrm{ml}$ concentration of $T$. nigrovenulosa resulted in $13.3,42.5,62.5$ and $86.7 \%$ at $1,3,5$ and $7 \mathrm{~h}$ after treatment, respectively against Pratylenchus coffeae. Concentration of $0.1,0.5,1.0$ and $2.0 \mathrm{mg} / \mathrm{ml}$ of $T$. nigrovenulosa resulted in 26.7, 71.7, 78.3 and $86.7 \%$ effectiveness respectively, at $7 \mathrm{~h}$ after treatment. Also, at 3 days after exposure to T. nigrovenulosa, hatch was inhibited by $60.0,45.8$, 17.5 and $5.8 \%$ at $0.1,0.5,1.0$ and $2.0 \mathrm{mg} / \mathrm{ml}$, respectively. Hatch was inhibited by $65.0,50.8,21.7$ and $6.7 \%$ at $0.1,0.5,1.0$ and $2.0 \mathrm{mg} / \mathrm{ml}$ respectively, at 6 days after exposure to T. nigrovenulosa. The mortality rate and hatch inhibition increased with increasing incubation time for crude extract of T. nigrovenulosa.
\end{abstract}

Trong nghiên cứu này, 5 cây thuốc (Cinnamomum camphora, Jasminum suptriplinerve, Premna integrifolia, Terminalia nigrovenulosa, Treptocaulon juventas) đã được sủ dụng làm nguyên liệu chiết xuất bằng methanol để thư hoạt tính kháng tuyến trùng Pratylenchus coffeae. Kết quả cho thấy chiết xuất tì̀ cây Terminalia nigrovenulosa biểu hiện hoạt tính kháng tuyến trùng cao nhất (95,0\%) sau 9 giờ xử lý với nồng độ $5 \mathrm{mg} / \mathrm{ml}$. Hoạt tính kháng tuyến trùng của các chất chiết xuất được biểu hiện theo thứ tụ giảm dần làn luợt là C. camphora (66,7\%), J. suptriplinerve (30,8\%), P. integrifolia $(6,7 \%)$ và $T$. juventas $(5,8 \%)$. Với nồng độ $2 \mathrm{mg} / \mathrm{ml}$ của chất chiết xuất tù T. nigrovenulossa biểu hiện hoạt tính gây chết tuyến trùng Pratylenchuss coffeae là 13,3; 42,5; 62,5 và $86,7 \%$ sau 1, 3, 5 và 7 giò̀ xủ lý theo thư tụ. Ở cùng thời điểm sau xủ lý 7 giò̀, các nồng độ 0,1; 0,$5 ; 1,0$ và 2,0 $\mathrm{mg} / \mathrm{ml}$ chiết xuất của T. nigrovenulossa có hoạt tính gây chết tuyến trùng Pratylenchus coffeae lần lượt là 26,7; 71,7; 78,3 và 86,7\%. Bên cạh đó, chất chiết xuất của T. nigrovenulossa cũng cho thấy tỷ lệ ức chế trứng nở cao. Cu thể là sau 3 ngày xủ lý với chất chiết xuất của $T$. nigrovenulossa, tỷ lệ úc chế trúng không nỏ là 60,$0 ; 45,8 ; 17,5$ và $5,8 \%$ at 0,$1 ; 0,5 ; 1,0$ và 2,0 $\mathrm{mg} / \mathrm{ml}$ theo thứ tụ. Sau 6 ngày xử lý với chất chiết xuất của T. nigrovenulossa, tỷ lệ ức chế trứng nở là 65,0; 50,8; 21,7 và 6,7\% tại nồng độ 0,1;0,5; 1,0 và 2,0 $\mathrm{mg} / \mathrm{ml}$ theo thư tụ. Tỷ lệ gây chết và tỷ lệ ức chế của chất chiết xuất phụ thuộc vào cả thời gian và nồng độ xủ lý.

Keywords: Medicinal plant, Pratylenchus coffeae, nematicidal activity, biocontrol 


\section{Introduction}

Root-lesion nematode is considered as important plant pathogens and has a wide host plant range (Castillo \& Vovlas, 2007). It is ranking second only to root-knot and cyst nematodes in terms of their worldwide impact on agricultural crops (Sasser \& Freckman, 1987). Pratylenchus coffeae is the predominant genera and is widely distributed in coffee plantations, causing great economic losses to both farmers and industry (Campos \& Villain, 2005).

Use of chemical nematicides is usually more effective than other strategies, they have caused significant environmental problems due to their toxic residues and associated environmental damage that resulted in severe restrictions on their use (Harish et al., 2008). As general awareness of the harmful effects of chemical pesticides increases and public attitudes towards environmental pollution changes, chemical nematicides are losing their popularity among farmers (Elbadri et al., 2008).

In fact, plant-derived extracts have long been a subject of research in an effort to develop alternatives to conventional insecticides usually safer and with minimal residual effects (Ntalli et al., 2010a). Several plant preparations have an environmentally and toxicologically safe, selective, and efficacious nematicidal potential (Javed et al., 2006; Dawar et al., 2008; Ntalli et al., 2009; Ntalli \& Caboni, 2012). These pesticidal compounds derived from plants are generally considered to be non-persistent under field conditions, as they are readily transformed by light, oxygen, or microorganisms into less toxic products. Therefore, fewer residues are expected to result from the use of these natural products (Aoudia et al., 2012; Akhtar et al., 2008; Ntalli et al., 2010b; Ntalli et al., 2010c; Caboni et al., 2012).

Medicinal plants usually produce many natural products, such as phenols, flavonoids, quinons, tannins, alkaloids, saponins, sterols, and volatile essential oils. These secondary metabolites have various functions, including antimicrobial, insecticide and appetite suppressant properties (Akhtar et al., 2008). Additionally, natural products are generally easily biodegradable; therefore, they do not tend to persist in the environment (Akhtar et al., 2008). For these reasons, the objective of this study was to test five medicinal plant extracts for their nematicidal potential toxicity against the root-lesion nematode, Pratylenchus coffeae in vitro.

\section{Materials and methods}

\subsection{Preparation of medicinal plant extracts}

Five locally available plants used in traditional medicine in Vietnam were collected and identified (WHO, 1990), namely: Cinnamomum camphora, Jasminum suptriplinerve, Premna integrifolia, Terminalia nigrovenulosa, and Treptocaulon juventas. The plant samples were cut into $3 \mathrm{~cm}$ pieces, placed in paper bags, dried by heating in an oven at $50^{\circ} \mathrm{C}$ for 3 days, and stored at room temperature. Dried plant samples $(\approx 200 \mathrm{~g})$ were then extracted in
$80 \%$ methanol at a ratio of $1: 5(\mathrm{v} / \mathrm{v}$, dry plant materi$\mathrm{al} /$ solvent) at $30^{\circ} \mathrm{C}$ with shaking at $150 \mathrm{rpm}$ for 7 days. The extracts were filtered through a Whatman No. 2 filter and concentrated using a vacuum rotary evaporator at $40^{\circ} \mathrm{C}$. Finally, the concentrated extracts were freeze-dried and stored in a refrigerator. These samples were used for the nematicidal activity assays and further purification of the active compounds.

\subsection{Collection of root-lesion nematodes}

The root-lesion nematode, Pratylenchus coffeae was isolated from the roots of infected coffee collected in the Central Highland of Vietnam. The roots were cut into 1$\mathrm{cm}$ pieces and then nematodes were separated using the Baermann funnel (Speijer \& De Waele, 1997). The nematodes were surface-sterilized with streptomycine sulphate 2,000 ppm. Carrot discs were prepared by using fresh carrots with green foliage. The carrots were carefully washed in tap water to remove soil debris and other adhering materials. They were surface-sterilized with $95 \%$ ethanol, flamed and peeled with a sterile potato peeler. The peeled carrots were cut into $5 \mathrm{~mm}$ thick discs. The carrot discs were placed individually into sterile $3.5 \mathrm{~cm}$ diameter Petri dishes, which were sealed with Parafilm and stored at room temperature in the dark. After 7 days, the nematodes had multiplied and could be seen on the Petri dish around the carrot disc. The Petri disc was rinsed with distilled water and poured the water through a $25 \mu \mathrm{m}$ sieve. Retained nematodes in the sieve were collected with distilled water in a beaker. A standard nematode suspension density was then adjusted by appropriate dilution with distilled water.

\subsection{Mortality bioassay of crude extracts}

Approximately 900 nematodes in $900 \mu$ of water were added to each well of a 24-well Misrotest ${ }^{\mathrm{TM}}$ Tissue Culture Plate and $100 \mu \mathrm{l}$ of crude extract were added at concentrations of $0,1.0,5.0,10$ and $20 \mathrm{mg} / \mathrm{ml}$. Therefore, the final concentrations of crude extracts in nematode suspension were $0,0.1,0.5,1.0$ and $2.0 \mathrm{mg} / \mathrm{ml}$. Control samples received $100 \mu$ of methanol. Treatments were replicated five times per trial. The plate was covered with the original solid lid and wrapped with Parafilm and were then held at $25 \pm 1^{\circ} \mathrm{C}$. To determine the effects of crude extracts on nematode survival, $20 \mu$ of nematode suspension was removed using a pipette and the number of dead nematodes was determined at $1,3,5,7$ and $9 \mathrm{~h}$ after treatment using a microscope. Nematicidal activity was estimated according to the mean percentage of paralyzed nematodes. Nematodes were considered as paralyzed if they did not move when probed with a fine needle (Cayrol et al., 1989). All treatments were replicated five times.

\subsection{Egg hatching inhibition bioassay of crude extracts}

A direct-contact bioassay was used to evaluate the toxicity of crude extracts to Pratylenchus coffeae eggs. Approximately 900 eggs in $900 \mu \mathrm{l}$ of water were added to each well of a 24-well Misrotest ${ }^{\mathrm{TM}}$ Tissue Culture Plate, and 
$100 \mu \mathrm{l}$ of crude extracts were added at concentrations of $0,1.0,5.0,10$ and $20 \mathrm{mg} / \mathrm{ml}$. Therefore, the final concentrations of crude extracts in egg suspension were $0,0.1$, $0.5,1.0$ and $2.0 \mathrm{mg} / \mathrm{ml}$. Control samples received $100 \mu \mathrm{l}$ of the methanol. The plate was then covered with the original solid lid and wrapped with Parafilm. Treated and control eggs were held at $25 \pm 1{ }^{\circ} \mathrm{C}$. The toxicity of crude extracts to the eggs was based upon the number of unhatched juveniles at 3 and 6 days after treatment, as observed under a microscope. All treatments were replicated five times.

\subsection{Statistical analyses}

The mortality of nematodes was calculated from the formula: Mortality $(\%)=[$ nematodes $($ dead $) /$ nematodes $($ live + dead) $] \times 100$. Percentage of inhibition of hatch $(\mathrm{PIH})$ was calculated from the formula: $\mathrm{PIH}=[(C-T) / C] \times 100$, where $C$ is the control percentage hatch and $T$ is the treated percentage hatch. To measure mortality, egg hatch inhibition, date was compared using Tukey's studentized range (HSD) test, with a $p \leq 0.05$ indicating statistical significance. All data were analyzed using the Statistical Analysis System 9.1 (SAS, 2004) and are presented as the mean value \pm standard deviation (S.D.).

\section{Results}

Five medicinal plant extracts were dissolved in methanol and typical characteristics of each extract such as colour and odour in the solvent were recorded (Table 1). The yield of medicinal plants was recorded after extraction as follows: T. nigrovenulosa (2.45\%), C. camphora $(2.28 \%)$, $J$. suptriplinerve $(1.85 \%), P$. integrifolia $(1.53 \%)$ and $T$. juventas $(0.87 \%)$.

Table 1. Typical characteristics of organic crude extracts obtained from native medicinal plants grown in Vietnam

\begin{tabular}{lccccc}
\hline \multicolumn{1}{c}{ Plant species } & Family & Used parts & Colour & Odour $^{(\mathbf{2})}$ & Yield (\%) $^{(\mathbf{3})}$ \\
\hline Cinnamomum camphora & Lauraceae & Bark & Brown & + & 2.28 \\
Jasminum suptriplinerve & Oleaceae & Leaves & Dark green & ++ & 1.85 \\
Premna integrifolia & Verbenaceae & Leaves & Dark green & ++ & 1.53 \\
Terminalia nigrovenulosa & Combretaceae & Bark & Brown & - & 2.45 \\
Treptocaulon juventas & Asclepiadaceae & Rhizome & Light yellow & + & 0.87 \\
\hline (1) Colour in methanol solvent & & & & &
\end{tabular}

Colour in methanol solvent

(2) - no odour; + aroma odour; ++ pungent odour

(3) (Dried weight of methanol extract/dried weight of the plant samples) $\times 100$

Nematicidal activity was significant difference among crude extracts over time. A $5 \mathrm{mg} / \mathrm{ml}$ concentration of crude extracts of $T$. nigrovenulosa, C. camphora, J. suptriplinerve, $P$. integrifolia and T. juventas resulted in 89.2,
59.2, 28.3, 6.7 and 5.8\% and 95.0, 66.7, 30.8, 6.7 and 5.8\% effectiveness respectively, at 7 and $9 \mathrm{~h}$ after treatment. There was no mortality in control (Table 2).

Table 2. The exposure effect of crude extracts obtained from medicinal plants on mortality of Pratylenchus coffeae at $1,3,5,7$ and $9 \mathrm{~h}$ after treatment with concentration of $5 \mathrm{mg} / \mathrm{ml}$

\begin{tabular}{|c|c|c|c|c|c|}
\hline \multirow[t]{2}{*}{ Plant species } & \multicolumn{5}{|c|}{ Mortality (\%) } \\
\hline & 1 & 3 & 5 & 7 & 9 \\
\hline Control & $0^{\mathrm{j}}$ & $0^{\mathrm{j}}$ & $0^{\mathrm{j}}$ & $0^{\mathrm{j}}$ & $0^{\mathrm{j}}$ \\
\hline C. camphora & $6.7 \pm 2.6^{\mathrm{hi}}$ & $11.7 \pm 2.6^{h}$ & $43.4 \pm 4.1^{\mathrm{e}}$ & $59.2 \pm 3.8^{\mathrm{d}}$ & $66.7 \pm 2.6^{\mathrm{c}}$ \\
\hline J. suptriplinerve & $5.8 \pm 2.0^{j}$ & $22.5 \pm 5.2^{g}$ & $27.5 \pm 2.7^{\mathrm{fg}}$ & $28.3 \pm 2.6^{f}$ & $30.8 \pm 2.0^{f}$ \\
\hline$P$. integrifolia & $0^{\mathrm{j}}$ & $1.7 \pm 1.2^{\mathrm{ij}}$ & $5.8 \pm 2.0^{\mathrm{i}}$ & $6.7 \pm 2.6^{\mathrm{hi}}$ & $6.7 \pm 1.8^{\mathrm{hi}}$ \\
\hline$T$. juventas & $0^{\mathrm{j}}$ & $0^{\mathrm{j}}$ & $4.8 \pm 1.8^{\mathrm{ji}}$ & $5.8 \pm 2.0^{\mathrm{i}}$ & $5.8 \pm 2.0^{\mathrm{i}}$ \\
\hline T. nigrovenulosa & $5.0 \pm 2.0^{\mathrm{ji}}$ & $31.7 \pm 2.6^{f}$ & $62.5 \pm 5.2^{\mathrm{cd}}$ & $89.2 \pm 2.0^{b}$ & $95.0 \pm 3.2^{\mathrm{a}}$ \\
\hline
\end{tabular}

Mortality values are mean of five replications \pm standard errors of the mean values. Values in a vertical column or a horizontal row followed by the same letter are not significantly different according to Tukey's studentised range test at $p \leq 0.05$.

The nematicidal activity of the crude extracts obtained from C. camphora, J. suptriplinerve and T. nigrovenulosa against Pratylenchus coffeae was evaluated at different concentrations (0, 0.1, 0.5, 1.0 and $2.0 \mathrm{mg} / \mathrm{ml}$; Fig. 1). The mortality of Pratylenchus spp. was $<30 \%$ at $7 \mathrm{~h}$ after treatment with concentrations of $J$. suptriplinerve (Fig. 1B). The mortality was $4.2,14.2,45.0$ and $61.7 \%$ effectiveness at $0.1,0.5,1.0$ and $2.0 \mathrm{mg} / \mathrm{ml}$ respectively, at $7 \mathrm{~h}$ after treatment with $C$. camphora (Fig. 1A). Treatment with $0.1,0.5,1.0$ and $2.0 \mathrm{mg} / \mathrm{ml}$ of $T$. nigrovenulosa resulted in $26.7,71.7,78.3$ and $86.7 \%$ respectively at $7 \mathrm{~h}$ after treatment (Fig. 1C). A $2.0 \mathrm{mg} / \mathrm{ml}$ concentration of $T$. nigrovenulosa was $13.3,42.5,62.5$ and $86.7 \%$, respectively against Pratylenchus spp. at 1, 3, 5 and $7 \mathrm{~h}$ after treatment, respectively (Fig. 1C). There was no mortality observed in response to treatment with $1 \%$ methanol as a control.

The hatching inhibition effects of crude extracts were evaluated by measuring hatch of juveniles of Pratylenchus spp. using direct-contact bioassay (Fig. 2). At 3 days after exposure to $\mathrm{T}$. nigrovenulosa, hatch was inhibited by $60.0,45.8,17.5$ and $5.8 \%$ at $0.1,0.5,1.0$ and $2.0 \mathrm{mg} / \mathrm{ml}$, respectively, followed by extracts of C. camphora and $\mathrm{J}$. 
suptriplinerve (Fig. 2A). Similarly, hatch was inhibited by $65.0,50.8,21.7$ and $6.7 \%$ at $0.1,0.5,1.0$ and $2.0 \mathrm{mg} / \mathrm{ml}$ at 6 days after exposure to T. nigrovenulosa, respectively. Control samples showed 62.5 and $66.7 \%$ at 3 and 6 days after treatment, respectively, followed by extracts of C. camphora and J. suptriplinerve (Fig. 2B). The inhibitory effect on hatching was increased by increasing the concentration.

\section{Discussion}
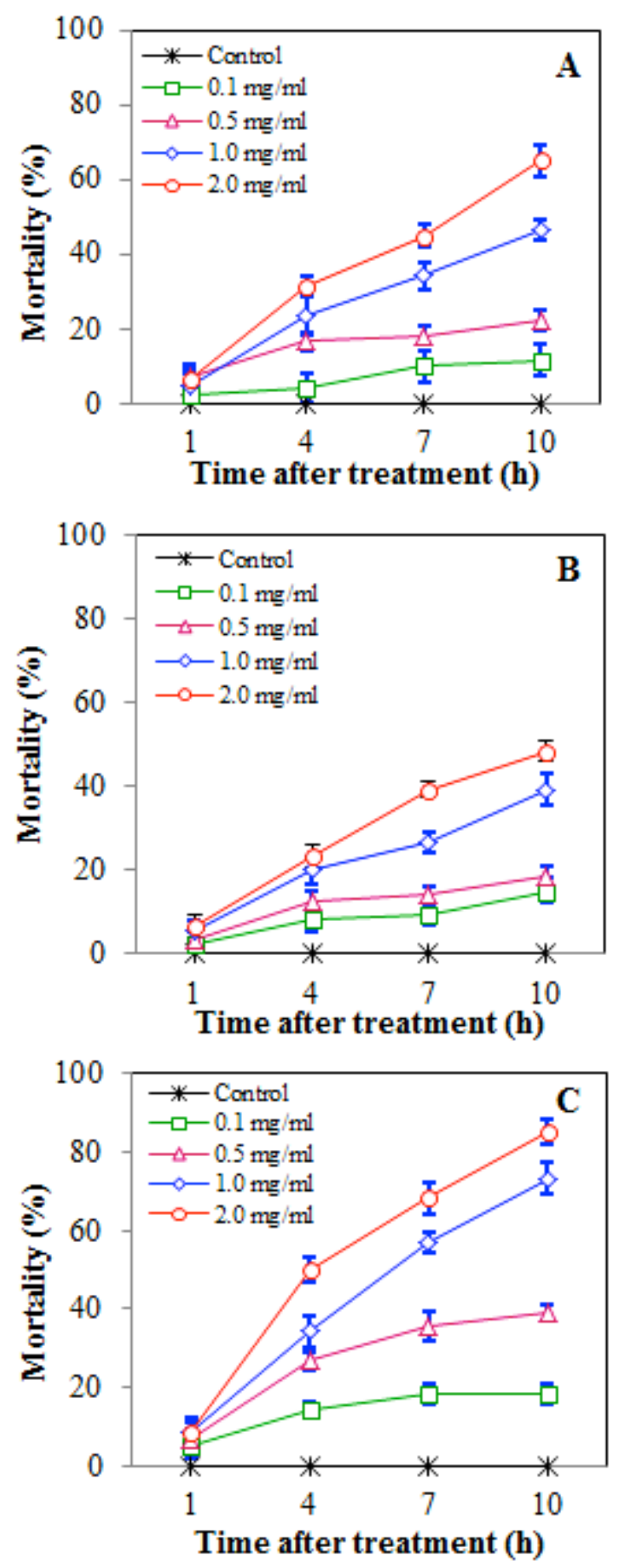

Figure 1. Nematicidal activity of various different concentrations $(0,0.1,0.5,1.0$ and $2.0 \mathrm{mg} / \mathrm{ml})$ of crude extracts obtained from Cinnamomum camphora (A), Jasminum suptriplinerve (B), and Terminalia nigrovenulosa (C) against Pratylenchus coffeae
Many phytochemicals are known to exert nematicidal activity. Compounds involved in treatment of plants associated with nematodes include repellants, attractants, hatching stimulants or inhibitors, and nematotoxicants. Such compounds can be either constitutive or formed in response to the presence of nematodes (Chitwood, 2002). As a result, more studies need to include as many plant taxa as possible to explore a wide range of phytochemicals that have the potential for use as alternatives to chemical nematicides. The nematicidal activity of some plant preparations, including essential oils against Meloidogyne spp. has been demonstrated (Oka, 200; Chitwood, 2002; Zasada et al., 2006). Medicinal plant extracted from Terminalia nigrovenulosa were effect on Meloidogyne and observed good nematicidal activity against juveniles and inhibition of egg hatching (Nguyen et al., 2013a; 2013b).
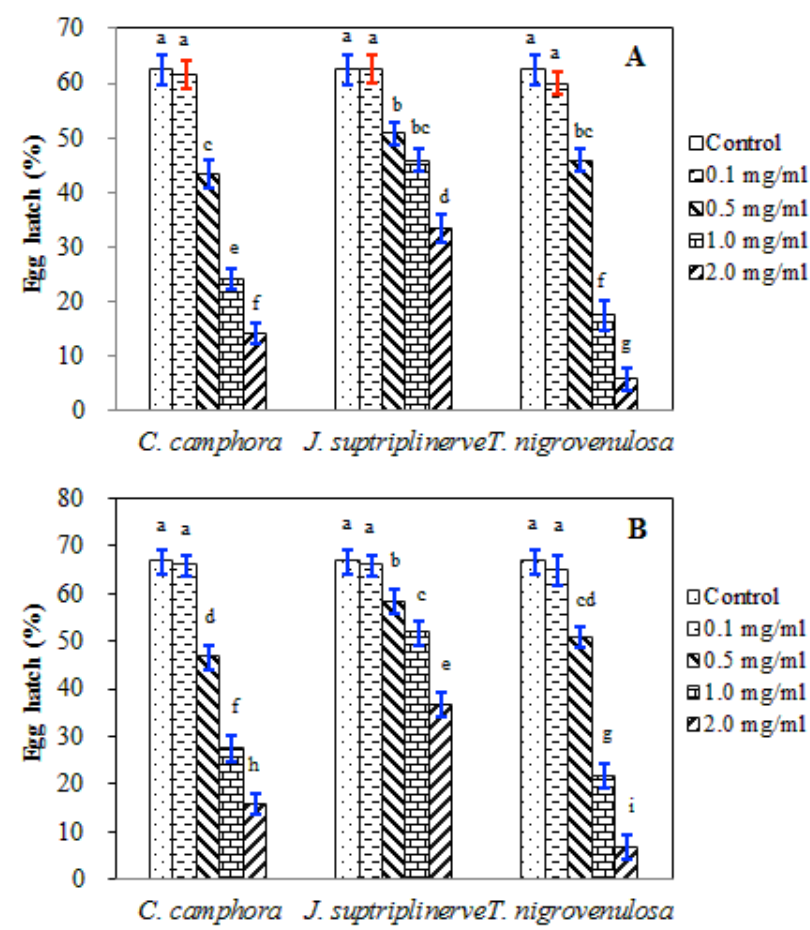

Figure 2. Inhibition of egg hatch of Pratylenchus coffe$a e$ by different concentrations of crude extracts $(0,0.1$, $0.5,1.0$ and $2.0 \mathrm{mg} / \mathrm{ml}$ ) obtained from Cinnamomum camphora, Jasminum suptriplinerve, and Terminalia nigrovenulosa using direct-contact bioassay at 3 and 6 days after treatment. Means followed by the same letter are not significantly different $(p \leq 0.05)$

In this study, T. nigrovenulosa crude extract exhibited potent nematicidal activity against Pratylenchus coffeae. The nematicidal activity was dependent on both the concentration and treated time of the $T$. nigrovenulosa extracts. The use of agricultural phytochemicals offers tremendous potential for the control of nematodes; however, it is currently not economically feasible in many situations (Chitwood, 2002). Moreover, while treatment with $0.45 \%$ colchicines was found to exert a nematicidal effect against $M$. incognita juveniles (Nidiry, 1993), the activity was insufficient to account for the toxicity of the source of the compound, seeds of Gloriosa superba (Liliaceae). The roots of the Madagascar periwinkle (Caharanthus 
roseus, Apocynaceae), which is a medicinal plant with anthelmintic activity, contain the pentacyclic alkaloid serpentine. Serpentine has been found to induce death and inhibit hatching of $M$. incognita at a concentration of 2 $\mathrm{mg} / \mathrm{ml}$ (Chandravadana, 1994), and treatment of tomato seeds with serpentine was found to inhibit subsequent infection by M. incognita (Rao, 1996).

Shukla \& Haseeb (1996) indicated that application of nematicides and oil cakes brought an appreciable increase in herb weight and oil yield of Mentha citrata, Mentha piperita and Mentha spicata and a reduction in the reproduction rate of Pratylenchus thornei. Neem cake was the most effective and linseed cake or carbofuran the least effective in improving the yield and in reducing reproduction rate of Pratylenchus thornei. The integration of carbofuran with neem cake and castor cake was most effective in increasing plant growth and yield with a decrease in root-lesion nematode population (Jothi et al., 2004). Meyer et al. (2006) used the extracts of Plantago lanceolata and $P$. rugelii against $M$. incognita and other beneficial and parasitic microbes. Both extracts were found to be toxic to $M$. incognita eggs and second-stage juveniles, with $P$. lanceolata extract tending to have the most activity. However, the extracts were not toxic to beneficial microbes such as Enterobacter cloacae, Pseudomonas fluorescens, and Trichoderma virens. This result showed that $T$. nigrovenulosa inhibited egg hatch of Pratylenchus. This is significant because the egg stage is the most resistant stage in the nematode's life cycle, possibly due to its 3-layer shell (Wharton, 2002).

To know the mode of action of extract is very important for the control of nematodes because it may provide useful information on the most appropriate formulation and delivery means. However, the mode of action of crude extracts against nematodes is unclear and should be further investigated. The relation between nematicidal and insecticidal has reported by Oka (2000).

The results of this study indicate that $T$. nigrovenulosa methanol extracts could be used for the biocontrol of plant parasitic nematodes, especially root-lesion nematode populations. This is a research area in which the results of many studies can be utilized for the benefit of phytonematode control. Further studies are needed to evaluate their nematicidal or hatch inhibition activities under in vivo test and to identify the chemical structure of the active compounds. After these structures are identified, commercial bio-nematicides may be developed as biological control agents of soil-borne phytopathogens in the field.

\section{Acknowledgements}

This study was financially supported by Chonnam National University, 2012.

\section{References}

[1] Akhtar, Y., Yeoung, R., Isman, M.B. 2008. Comparative bioactivity of selected extracts from Meliaceae and some commercial botanical insecticides against two noctuid caterpillars, Trichoplusia $n i$ and Pseudaletia unipuncta. Phytochem Rev 7: 77-88.

[2] Aoudia, H., Ntalli, N., Aissani, N., Yahiaoui-Zaidi, R., Caboni, P. 2012. Nematotoxic phenolic compounds from Melia azedarach against Meloidogyne incognita. J Agric Food Chem 60: 11675-11680.

[3] Caboni. P., Ntalli, N.G., Aissani, N., Cavoski, I., Angioni, A. 2012. Nematicidal Activity of (E,E)2,4-Decadienal and (E)-2-Decenal from Ailanthus altissima against Meloidogyne javanica. J Agric Food Chem 60: 1146-1151.

[4] Campos, V.P., VILLAIN, L. 2005. Nematode parasites of coffee, cocoa and tea. In: Luc, M., Sikora, R.A. \& Bridge, J. (Eds). Plant-parasitic nematodes in subtropical and tropical agriculture. Wallingford, UK, CAB International: 387-430.

[5] Castillo, P., Vovlas, N. 2007. Pratylenchus, (Nematoda, Pratylenchidae): diagnosis, biology, pathogenicity and management. Nematology Monographs and Perspectives 6: $529 \mathrm{p}$.

[6] Cayrol, J.C., Djian, C., Pijarowiski, L. 1989. Study on the nematicidal properties of the culture filtrate of the nematophagus fungus Paecilomyces liacinus. Revue de Nematologie 12: 331-336.

[7] Chandravadana, M.V., Nidiry, E.S.J., Khan, R.M., Rao, M.S. 1994. Nematicidal activity of serpentine against Meloidogyne incognita. Fundamental and Applied Nematology 17: 185-192.

[8] Chitwood, D.J. 2002. Phytochemical based strategies for nematode control. Annual Review of Phytopathology 40: 221-249.

[9] Dawar, S., Sattar, A., Zaki, M.J. 2008. Seed dressing with biocontrol agents and nematicides for the control of root knot nematode on sunflower and okra. Pak J Bot 40: 2683-2691.

[10] Elbadri, G.A., Lee, D.W., Park, J.C., Yu, H.B., Choo, H.Y. 2008. Evaluation of various plant extracts for their nematicidal efficacies against juveniles of Meloidogyne incognita. J Asia-Pacific Entomol 11: 99-102.

[11] Harish, S., Saravanakumar, D., Radjacommare, R., Ebenezar, E.G., Seetharaman, K. 2008. Use of plant extracts and biocontrol agents for the management of brown spot disease in rice. BioControl 53: 555-567.

[12] Javed, N., Gowen, S.R., Inam, U.1 Haq, M., Abdullah, K., Shahina, F. 2006. Systemic and persistent effect of neem (Azadirachta indica) formulations against root-knot nematodes, Meloidogyne javani$c a$ and their storage life. Crop Prot 26: 911-916.

[13] Jothi, G., Babu, R.S., Ramakrishnan, S., Rajendran, G. 2004. Management of root lesion nematode, Pratylenchus delattrei in crossandra using oil cakes. Bioresource Technology 93: 257-259

[14] Meyer, S.L.F., Zasada, I.A., Roberts, D.P., Viviard, B.T., Lakshman, D.K., Lee, J.K., Chitwood, D.J., 
Carta, L. 2006. Plantago lanceolata and Plantago rugelii extracts are toxic to Meloidogyne incognita but not to certain microbes. Journal of Nematology 38: 333-338.

[15] Nguyen, D.M.C., Seo, D.J., Kim, K.Y., Kim, T.H., Jung, W.J. 2012. Nematode-antagonistic effects of Cinnamomum aromaticum extracts and a purified compound against Meloidogyne incognita. Nematology 14: 913-924.

[16] Nguyen, D.M.C., Seo, D.J., Kim, K.Y., Park, R.D., Kim, D.H., Han, Y.S., Kim, T.H., Jung, W.J. 2013a. Nematicidal activity of 3,4Dihydroxybenzoic acid purified from Terminalia nigrovenulosa bark against Meloidogyne incognita. Microb. Pathogenesis 59: 52-59.

[17] Nguyen, D.M.C., Seo, D.J., Nguyen, V.N., Kim, K.Y., Park, R.D., Jung, W.J. 2013b. Nematicidal activity of gallic acid purified from Terminalia $n i-$ grovenulosa bark against the root-knot nematode Meloidogyne incognita. Nematology 15(5): $507-$ 518.

[18] Nguyen, D.M.C., Nguyen, V.N., Seo, D.J., Park, R.D., Jung, W.J. 2009. Nematicidal activity of compounds extracted from medicinal plants against the pine wood nematode Bursaphelenchus $x y$ lophilus. Nematology 11: 835-845.

[19] Nidiry, E.S.J., Khan, R.M., Reddy, P.P. 1993. In vitro nematicidal activity of Gloriosa superba seed extract against Meloidogyne incognita. Nematologia Mediterranea 21: 127-128.

[20] Ntalli, N.G., Caboni, P. 2012. Botanical nematicides: A review. J Agric Food Chem 60: 99299940.

[21] Ntalli, N.G., Ferrari, F., Giannakou, I., Menkissoglu-Spiroudi, U. 2010a. Phytochemistry and nematicidal activity of the essential oils from 8 Greek Lamiaceae aromatic plants and 13 terpene components. J Agric Food Chem 58: 7856-7863.

[22] Ntalli, N.G., Ferrari, F., Giannakou, I., Menkissoglu-Spiroudi, U. 2010b. Synergistic and antagonistic interactions of terpenes against Meloidogyne incognita and the nematicidal activity of essential oils from seven plants indigenous to Greece. Pest Manag Sci 67: 341-351.

[23] Ntalli, N.G., Menkisoglou-Spiroudi, U., Giannakou, I.O., Prophetou-Athanasiadou, D.A. 2009. Ef- ficacy evaluation of a neem (Azadirachta indica A. Juss) formulation against root-knot nematodes Meloidogyne incognita. Crop Prot 28: 489-494.

[24] Ntalli. N.G., Menkissoglu-Spiroudi, U., Giannakou, I. 2010c. Nematicidal activity of powder and extracts of Melia azedarach fruits against Meloidogyne incognita. Ann Appl Biol 156: 309-317.

[25] Oka, Y. 2000. Nematicidal activity of essential oils and their components against the root-knot nematode. Nematology 90: 710-715.

[26] Rao, M.S., Reddy, P.P., Mittal, A., Chandravadana, M.V., Nagesh, M. 1996. Effect of some secondary plant metabolites as seed treatment agents against Meloidogyne incognita on tomato. Nematologia Mediterranea 24: 49-51.

[27] SAS 2004. SAS/STAT User's Guide, version 9.1. Cary, NC, USA, SAS Institute.

[28] Sasser, J.N., Freckman, D.W. 1987. A world perspective on nematology: the role of the society. In: Veech, J.A. and Dickerson, D.W. (eds), Vistas on nematology. Society of Nematologists, Hyattsville, Maryland: 7-14.

[29] Shukla, P.K., Hasseb, A. 1996. Effectiveness of some nematicides and oil cakes in the management of Pratylenchus thornei on Mentha citrate, $M$. piperita and M. spicata. Bioresource Technology 57: 307-310.

[30] Speijer, P.R., Waele, D.D. 1997. Screening of Musa germplasm for resistance and tolerance to nematodes. INIBAP Technical Guidelines 1. International Network for the Improvement of Banana and Plantain, Montpellier, France, $47 \mathrm{p}$.

[31] WHO/WPRO. 1990. Medicinal plants in Vietnam. Institute of Materia, Hanoi, 444 pp.

[32] Yagi, K., Williams, N.Y., Cicerone, R.J. 1993. Agricultural soil fumigation as a source of atmospheric methyl brome. Proceedings of the National Academy of Sciences of the United States of America 90: 8420-8423.

[33] Zasada, I.A., Klassen, W., Meyer, S.L.F., Codallo, M., Abdul-Baki, A.A. 2006. Velvetbean (Mucuna pruriens) extracts: impact on Meloidogyne incognita survival and on Lycopersicon esculentum and Lactuca sativa germination and growth. Pest Management Science 62: 1122-1127. 